\title{
PERENCANAAN LANSKAP KAWASAN PENERAPAN INOVASI TEKNOLOGI PETERNAKAN PRUMPUNG BERBASIS RAMAH LINGKUNGAN
}

\section{Landscape Planning for The Implementation of Environmentally Friendly Prumpung Livestock Technology Inovation Areas}

\author{
Djatmiko Pinardi, Anton Gunarto, Santoso
}

Agricultural Production Technology Center, Agency for the Assessment and Application of Technology Laptiab Gd. 612 Puspiptek Serpong Tangerang Selatan

E-mail: djatmikopinardi@gmail.com

\begin{abstract}
The needs of animal protein especially of meats, is increasing from year to year in line with the rising numbers of people as well as an enhanced awareness of Indonesian people about fulfilling the nutrition. One of the efforts can be done to get fresh meat for consumption at their own volition was by raising the standard of the population and productivity of low class ruminants to set up their cattle on a more sustainable path. The purpose of this activity was proposed the framework for the landscape of a planning at the office of KAPITAN that serves as a means of the dissemination of technological innovations, a place to conduct field studies and mean engineering technology and shall be promulgated by the application of the concept of GFP. Material and methode to materialize this needs to be a manual the cultivation of its beef cattle (Good Farming Practices). The concept of GFP is the application of the efficiency of production with must pay attention to the environmental factors in the business of a farm. Several factors that must be considered include cattle that are reared, feed given, the management of the cost of maintenance, left the care of his facilities as well as the surrounding environment. The concept of GFP is the application of the efficiency of production with must pay attention to the environmental factors in the business of a farm. Several factors that must be taken care are its industrial activity among others cattle that are reared, feed given, the management of the cost of maintenance, the facilities of maintenance as well as the surrounding environment. Result and discussions, the application of the concept of GFP requires good managerial and qualified human resources to maintain under strict supervision and in a continuous way. The department for The Assessment and Application of Technology (BPPT) that plan to build "the area of the application of technological innovations of animal husbandry (KAPITAN) Prumpung Gunung Sindur Bogor districts" is trying to participate in the application of the concept of GFP. Conclusion, Kapitan Prumpung is expected to beneficial in helping on the development of food security in the delivery of animal protein origin of ruminants through innovation in the field of animal husbandry and the increase in human resources of animal husbandry
\end{abstract}

Keywords: Husbandry Landscape, Good Farming Practices, Environmental Friendly

\section{PENDAHULUAN}

Pengembangan ternak ruminansia sapi dan kambing merupakan salah satu komoditas strategis yang mendukung ketahanan pangan dalam penyediaan kebutuhan pangan protein asal ternak. Inovasi teknologi peternakan ruminansia sapi dan kambing perlu dilakukan sehingga diperoleh produktivitas ternak ruminansia yang optimal.

Menghadapi AEC (ASEAN Economic Community) 2015 bidang pangan terutama produk peternakan secara khusus diperlukan standarisasi yang ketat sehingga perlu diterapkan konsep Good Animal Husbandry Practices (GAHP). Penerapan GAHP bertujuan menjamin bahwa produk perternakan yang dihasilkan aman untuk dikonsumsi dengan kualitas yang tepat dan sesuai bagi konsumen, selain itu juga memastikan produk peternakan tersebut dihasilkan dengan cara yang benar tanpa menimbulkan kerugian/kerusakan lingkungan, kesehatan, keselamatan dan kesejahteraan pekerja di sektor peternakan. 
Konsep GAHP dapat dicapai melalui penerapan efisiensi produksi dengan tetap memperhatikan faktor lingkungan dan semua yang terlibat dalam usaha peternakan. Beberapa faktor yang harus diperhatikan antara lain ternak yang dipelihara, pakan yang diberikan, manajemen pemeliharaan, fasilitas pemeliharaan serta lingkungan sekitarnya. Traceability dari produk peternakan yang dihasilkan harus jelas, baik itu ternaknya, pakan, proses produksi/pemeliharaan, pemotongan, pengolahan hingga distribusi ke tangan konsumen. Penerapan konsep GAHP membutuhkan SDM yang berkualitas untuk menjalankannya disertai dengan pengawasan yang ketat dan berkelanjutan.

Badan Pengkajian dan Penerapan Teknologi (BPPT) yang mempunyai tugas dan fungsi di bidang pengkajian dan penerapan teknologi sesuai dengan ketentuan peraturan perundang-undangan yang berlaku, berupaya berperan serta dalam pengembangan sektor peternakan dengan penerapan konsep GAHP di Indonesia yaitu "Kawasan Penerapan Inovasi Teknologi Peternakan (KAPITAN) Prumpung” dibawah unit teknis bidang peternakan Pusat Teknologi Produksi Pertanian, BPPT.

Tujuan penelitian adalah menyusun konsep perencanaan lanskap KAPITAN yang berfungsi sebagai sarana diseminasi inovasi teknologi, tempat kajian dan perekayasaan teknologi, lokasi percontohan, kebun koleksi hijauan makanan ternak (HMT), lokasi pelatihan/magang/training, serta pelayanan reproduksi dan kesehatan hewan pada kegiatan peternakan ruminansia berkonsep GAHP yang berwawasan lingkungan. Kegiatan di KAPITAN ini diharapkan bermanfaat dalam membantu pembangunan berkelanjutan (sustainable development) melalui inovasi di bidang peternakan dalam rangka peningkatan penyediaan protein hewani asal ternak ruminansia. Menurut Mersyah (2005) bahwa kriteria acuan pembangunan berkelanjutan pada prinsipnya menyangkut dimensi ekologi, dimensi ekonomi, dimensi sosial-budaya, dimensi hukumkelembagaan serta dimensi teknologi.

\section{MATERI DAN METODE}

Penelitian dilaksanakan mulai Januari hingga Desember 2016. Lokasi penelitian di Prumpung, Desa Gunung Sindur, Kecamatan Gunung Sindur, Kabupaten Bogor, Propinsi Jawa Barat. Status Tanah Milik BPPT dengan luas lahan 9,7 ha.

Materi
Jenis data yang diperlukan yaitu data primer dan data sekunder. Data primer diperoleh melalui wawancara, survei lokasi dan observasi. Sedangkan data sekunder diperoleh dari laporan, literatur, publikasi dan dokumen lainnya dari lembaga/instansi terkait. Beberapa informasi data terdiri dari aspek biofisik, aspek teknik dan aspek sosial ekonomi.

\section{Metode}

Penelitian ini menggunakan metode deskriptif dengan survei lapang untuk mendapatkan data secara langsung. Proses desain penelitian ini mengikuti proses pendekatan metode framework perencanaan yang terdiri dari persiapan, inventarisasi, analisis, sintesis hingga konsep perencanaan taman, antara lain berupa konsep perencanaan lanskap yang sesuai dengan fungsi dalam tapak (zonasi, penataan, sirkulasi, fasilitas), aktifitas dan keinginan pengguna (Gold, 1980).

\section{HASIL DAN PEMBAHASAN}

\section{Kondisi Awal Kawasan}

Lokasi KAPITAN Prumpung terletak pada koordinat 6 23'00" LU - 6 23'12" LS dan 106 39'16" BB - 106'39'28” BT. Vegetasi yang dominan adalah tanaman liar yang kerap menjadi gulma seperti prumpung (Phragmites karka), alang-alang (Imperata cylindrica), rumput japang (Paspalum conjugatum), Cynodon dactylon, teki dari keluarga Cyperaceae, gulma berdaun lebar serta beberapa jenis gulma lainnya. Sementara tanaman pertaniannya adalah singkong, pisang, kelapa dan bambu. Topografinya relatif landai namun sebagian besar luas lahannya merupakan bekas galian liar yang telah tergali setinggi 1-3 m, sehingga top soil permukaannya sudah hilang dan sudah menjadi lahan marjinal, hanya sebagian kecil luas lahan yang masih subur terletak di tepi kali Cihoe. Akibat galian tersebut topografinya menjadi tidak beraturan dan perlu ada revitalisasi dan rehabilitasi lahan. Untuk itu perlu dilakukan sesuatu upaya reklamasi lahan agar dapat meningkatkan kualitas lingkungan sehingga lahannya dapat bermanfaatkan kembali.

\section{Analisis dan Sintesis}

Sekitar KAPITAN Prumpung kondisi topografi umumnya relatif datar tidak ada perbukitan. Suhu udara berdasarkan data BMKG Stasiun Dramaga, pada tahun 2016 rata-rata berkisar $22,7^{\circ} \mathrm{C}$ s/d $31,6^{\circ} \mathrm{C}$, maksimum terjadi pada September yaitu $36,0^{\circ} \mathrm{C}$, sedangkan suhu udara minimum terjadi pada September yaitu 
$19,2^{\circ} \mathrm{C}$. Curah hujan di suatu tempat dipengaruhi oleh keadaan iklim, geografis dan pertemuan arus udara. Berdasarkan data BMKG Stasiun Curug Serpong, bahwa tahun 2014 Kecamatan Gunung Sindur sering diguyur hujan, dengan curah hujan tertinggi terjadi pada Januari 2014 sebesar 929 $\mathrm{mm}$, dan terendah pada Oktober yaitu $22 \mathrm{~mm}$.

Berdasarkan analisis fisik yang telah dilakukan, dapat diperoleh hasil berupa kondisi fisik KAPITAN memiliki potensi untuk dikembangkan menjadi sebuah demfarm peternakan, kebun koleksi pertanian, kolam perikanan dan objek agro-edu-wisata sekaligus dalam satu tapak sesuai dengan kondisi di Kecamatan Gunung Sindur .

\section{Konsep Dasar dan Desain}

Konsep dasar pengembangan KAPITAN adalah peternakan ruminansia (sapi dan kambing) berbasis GAHP yang berwawasan lingkungan. Sarana utama yang dirancang dalam KAPITAN adalah sarana untuk diseminasi inovasi teknologi peternakan. Penambahan fasilitas pertanian dan perikanan dalam perancangan ini adalah untuk mewujudkan konsep integrasi yang berkelanjutan. Konsep dasar ini mencoba memadukan kekuatan integrasi peternakan dengan pertanian berekologis, sehingga memunculkan model peternakan yang produktif, efisien, dan berkualitas dengan resiko yang lebih kecil sekaligus ramah lingkungan. KAPITAN merupakan lahan yang tepat untuk menerapkan sistem peternakan GAHP, selain digunakan untuk kepentingan inovasi teknologi, KAPITAN dapat dijadikan percontohan peternakan bagi para pemerhati untuk datang ke lokasi, sehingga sarana tersebut juga dapat dimanfaatkan untuk kegiatan agro-edu-wisata. Oleh karena itu, konsepnya berupaya memadukan antara konsep penataan demfarm peternakan, tanaman hijauan dan pertamanan yang berpedoman pada kaidahkaidah estetika (keindahan) dan fungsional (kegunaan) suatu kawasan yang berkelanjutan dan ramah lingkungan.

Konsep desain pada perancangan KAPITAN ini adalah geometris alami. Pola geometris memberikan keuntungan berupa mudahnya pengaturan drainase, pengelolaan limbah, serta pemanfaatan sinar matahari. Konsep ini merupakan kombinasi antara bentukan geometris yang didukung oleh peran penataan elemen-elemen halus tapak (Fahrudin dan Hadi, 2013).

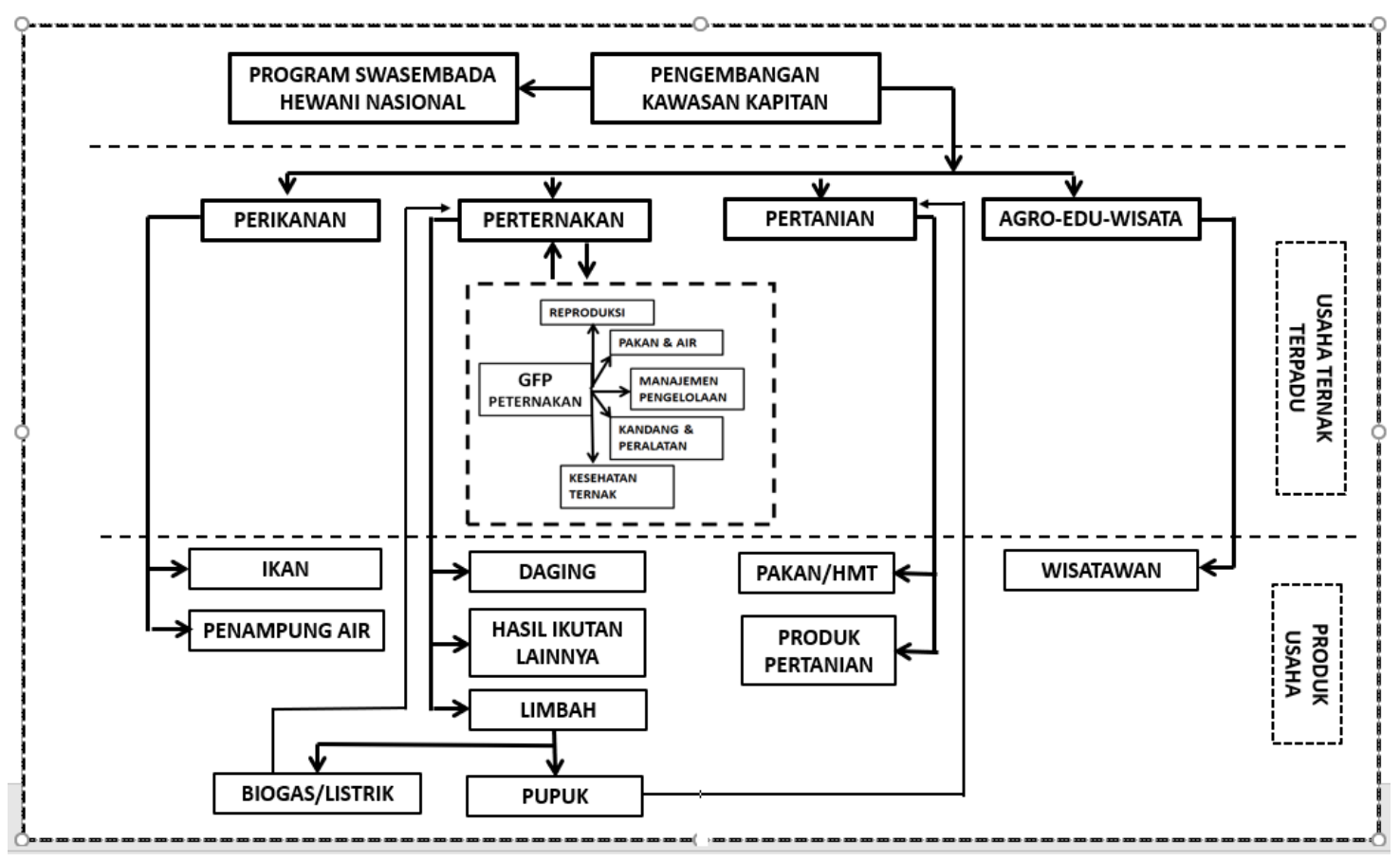

Gambar 1. Konsep Pengembangan Kawasan Kapitan 
Upaya untuk mengembangkan KAPITAN perlu diketahui profilnya antara lain meliputi: Pembibitan dan penggemukan sapi dan kambing, pengolahan pupuk cair, pupuk padat dan biogas, pengolahan pakan ternak, pusat pelatihan reproduksi, pakan ternak dan kesehatan hewan, serta sarana kajian dan penelitian peternakan ruminansia. Kegiatan unit pembibitan dan penggemukan yaitu sapi dan kambing masing masing dengan kapasitas 50 ekor. Fasilitas pendukung kegiatan ini adalah kandang betina, kandang anak dan kadang pembesaran. Kegiatan pembibitan akan mengaplikasikan teknologi reproduksi, teknologi kesehatan hewan dan manajemen pemeliharaan. Kegiatan pengolahan limbah akan mengusahakan pemanfaatan limbah menjadi barang yang bernilai ekonomis. Potensi dari limbah peternakan sangat besar bila dilihat dari jumlah ternak. Kegiatan pengolahan pakan ternak adalah untuk pemenuhan kebutuhan pakan ternak di KAPITAN sekaligus mengaplikasi teknologi pengolahan pakan ruminansia menggunakan bahan baku lokal dan pakan tambahan (feed aditif). Sementara kegiatan pelayanan reproduksi dan kesehatan hewan akan membantu di Kawasan KAPITAN dan wilayah sekitar dalam mengatasi masalah reproduksi dan kesehatan agar dapat meningkatkan produktivitas ternaknya. KAPITAN sebagai tempat pelatihan di bidang reproduksi, pakan dan kesehatan hewan yang bertujuan untuk meningkatkan pengetahuan dan penguasaan teknologi peternakan bagi mayarakat/peternak. Sekaligus sebagai pusat kajian inovasi teknologi peternakan ruminansia yang baru dan kekinian.

Zona adalah kawasan atau area yang memiliki fungsi dan karakteristik lingkungan yang spesifik. Zoning atau zonasi adalah pemecahan /penentuan suatu areal tertentu menjadi beberapa bagian, sesuai fungsi dan tujuan pengelolaan dan atau sesuai dengan peruntukannya, serta kondisi dan potensi kawasannya agar dapat diciptakan pengelolaan yang tepat, efektif dan efisien.

Pengembangan kawasan KAPITAN berdasarkan konsep GAHP menurut Eckbo (1995) adalah konsep ruang yang dibagi ke dalam beberapa zona dan masing-masing zona memiliki sub-zona yang fungsi ruangnya lebih spesifik. Zona yang dibuat dalam perancangan ini adalah: (1) Zona umum, berfungsi sebagai area penerima bagi para pengunjung atau sebagai forum edukasi dan interpretasi; (2) Zona Peternakan, berfungsi sebagai kegiatan peternakan ruminansia yaitu sapi dan kambing/domba; (3) Zona Pertanian, berfungsi sebagai kebun koleksi (plasma nutfah) pohon pakan ternak, serta kebun koleksi buahbuahan; (4) Zona Perikanan, berfungsi sebagai kolam ikan riset budidaya dan kolam rekreasi; dan (5) Zona Sumber Air, berfungsi sebagai penyediaan sumber air, baik untuk kebutuhan air bagi ternak, tanaman dan para pekerja atau pengunjung.

Adapun beberapa pertimbangan dirancangnya zonasi tersebut, adalah: (1) Diasumsikan bahwa lahan sudah dilakukan cut and fill sehingga lahan dianggap datar/landai, (2) Diasumsikan bahwa lahan sudah direhabilitasi dan direvitalisasi sehingga lahan dianggap sudah siap tanam dan siap bangun, (3) Kegiatan utama peternakan fokus ditengah-tengah lahan, terutama kandang dan sapras khusus, agar kegiatan peternakan tidak mengganggu warga di sekitar KAPITAN, (4) Dari segi keamanan untuk menghindari/mencegah pencurian hewan ternak dan peralatan yang ada, (5) Kawasan dibatasi selain oleh pagar beton di sekeliling, sehingga terhindar dari orang-orang liar yang keluarmasuk ke kawasan KAPITAN.

Aksesibilitas merupakan ukuran kenyamanan atau kemudahan suatu tata guna lahan berinteraksi satu sama lain dan mudahnya lokasi tersebut dicapai melalui sistem jaringan transporttasi (Black, 1981). Sirkulasi adalah prasarana penghubung vital yang menghubungkan berbagai kegiatan dan penggunaan dalam sebuah tapak di atas lahan. Sistem sirkulasi menggambarkan seluruh polapola pergerakan kendaraan, barang, dan pejalan kaki di dalam dan keluar-masuk tapak. Selain itu, sistem sirkulasi dalam tapak juga menghubungkan tapak tersebut dengan jaringan sistem sirkulasi di luar tapak. Konsep sirkulasi di dalam KAPITAN terdiri dari: (1) Jalan Utama, yang dicirikan oleh sirkulasi kendaraan logistik dan parker; (2) Jalan lingkungan, yang dicirikan oleh jalan untuk sirkulasi traktor, hewan ternak, pekerja dan pengunjung, yang relatif lebih cepat dari pejalan kaki; (3) Jalan kebun, dicirikan oleh sirkulasi jalan untuk pekerja/pekebun dengan jalan kaki; dan (4) Jalan inspeksi, dicirikan oleh sirkulasi jalan yang khusus diperuntukan bagi security (keamanan) dan sepeda atau sepeda motor.

\section{Perancangan Lanskap}

Perancangan tapak (landscape site planning) yang dalamnya tercakup desain landskap merupakan usaha penanganan tapak (site) secara optimal melalui proses keterpaduan penganalisaan dari suatu tapak dan kebutuhan program penggunaan tapak, menjadi suatu sintesa yang kreatif. Sedangkan perencanaan tapak adalah pengolahan fisik tapak untuk meletakkan seluruh kebutuhan rancangan di 
dalam tapak. Perencanaan tapak dilakukan dengan memperhatikan kondisi tapak dan kemungkinan dampak yang muncul akibat perubahan fisik di atasnya. Tujuan dari perencanaan tapak adalah agar keseluruhan program ruang dan kebutuhannya dapat diwujudkan secara terpadu dengan memperhatikan kondisi lingkungan alam, lingkungan fisik buatan, dan lingkungan sosial disekitarnya. Menciptakan ruang atau tapak sebagai wadah kegiatan manusia agar tercapai ruang yang nyaman, aman, sehat dan estetis (Hakim, 2012).
Sarana dan prasarana yang harus di perhatikan dalam sebuah kebun percobaan menurut (Fahrudin dan Hadi, 2013) adalah: (1) Bangunan, seperti kantor kebun, bangunan penelitian pengkajian (litkaji) dan gudang; (2) Lahan kebun percobaan, antara lain blok-blok lahan untuk kajian, koleksi, produksi, show window dan fungsi-fungsi lain; dan (3) Fasilitas pendukung lain, seperti: stasiun meteorologi, jalan kebun, pagar kebun, fasilitas pengeringan, bengkel, pos keamanan, saluran irigasi, sarana angkutan, peralatan, dan alat komunikasi.

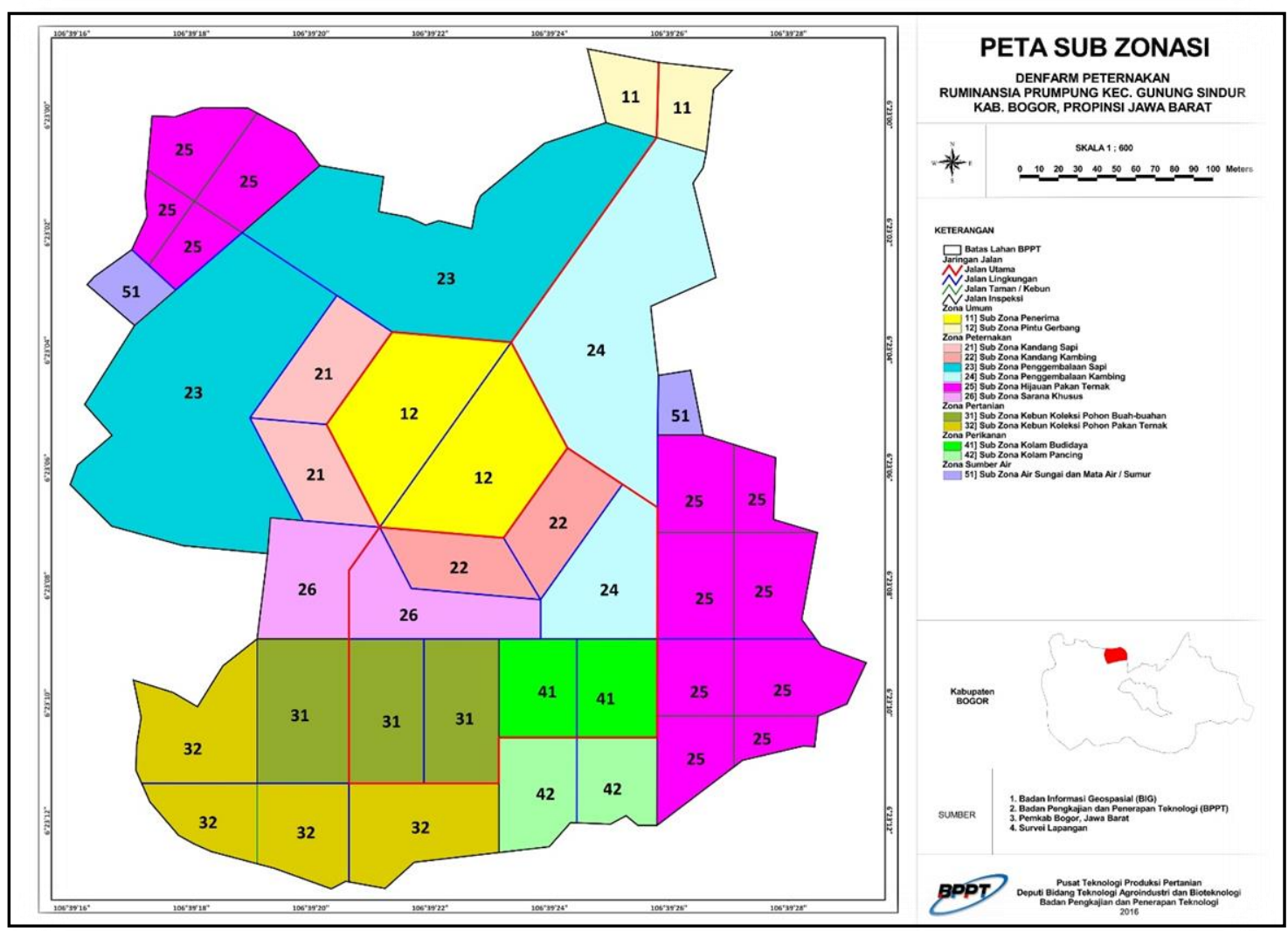

Gambar 2. Peta Sub Zonasi

Tapak KAPITAN seluas 9,7 Ha yang dirancang sebagai demfarm percontohan dan litkaji peternakan kapasitas pemeliharaan 50 Sapi dan 50 kambing terdiri dari lima Zona dan 14 Subzona dengan fasilitas saprasnya pada Gambar 2 sebagai berikut:

1. Zona Umum, seluas $0,02 \mathrm{Ha}(0,21 \%)$ terdiri dari Subzona Pintu Gerbang dan Subzona Penerima, yaitu: gedung kantor dan penerima (visitor centre) mushola, toilet serta area parkir.

2. Zona Peternakan, seluas $6,16 \mathrm{Ha}(63,53 \%)$ terdiri dari: a) Subzona Kandang Sapi untuk penggemukan, breeding, dan karantina; b) Subzona Kandang Kambing untuk penggemukan, breeding, dan karantina; c) Subzona Penggembalaan Sapi, yaitu: area penggembalaan, hijauan rumput, pagar ternak, pohon peneduh dan menara pandang; d) Subzona Penggembalaan Kambing: area penggembalaan, hijauan rumput, pagar ternak, pohon peneduh dan menara pandang; e) Subzona Hijauan Pakan Ternak (HPT), yaitu: area kebun dari beberapa jenis tanaman hijauan pakan ternak (semusim); f) Subzona Sapras Khusus, terdiri daria; 
bangunan handling ternak, gudang pakan dan ruang peneliti, ruang anak kandang, ruang pupuk cair dan padat, instalasi biogas, serta gazebo.

3. Zona Pertanian, seluas $2 \mathrm{Ha}(20,62 \%)$ terdiri dari subzona Kebun Buah-buahan dan subzona Area Kebun Pohon untuk pakan ternak (Tahunan) dan gazebo.

4. Zona Perikanan, seluas 0,5 Ha $(5,16 \%)$ terdiri dari subzona Kolam Riset Budidaya beberapa jenis ikan air tawar budidaya dan subzona Kolam Pancing beberapa jenis ikan air tawar dan gazebo.

5. Zona Sumber Air, seluas $1,02 \mathrm{Ha}(10,48 \%)$ terdiri dari subzona Air Sungai untuk reservoar air, tangki air, rumah pompa, air irigasi, area pengendalian limbah dan subzona Air Tanah (sumur bor) untuk reservoar air, tangki air, rumah pompa, air irigasi.

Rancangan tapak didominasi oleh penggunaan elemen lunak yang terkait dengan kegiatan peternakan. Elemen lunak di tapak didominasi oleh rumput penggembalaan, tanaman HMT, pohon koleksi pakan ternak dan buah-buahan dengan mayoritas komoditas tanaman produksi, serta kolam ikan yang kesemua elemen lunak tersebut sebagai penciri khas kawasan. Vegetasi pada taman-taman tematiknya pun yang dipilih diharapkan bisa memecah kekakuan pola geometris tapak. Elemen keras di tapak hanya diterapkan pada elemen-elemen tertentu seperti bangunan, jalur sirkulasi, plaza, signage dan site furniture. Site plan KAPITAN bisa dilihat pada Gambar 3.

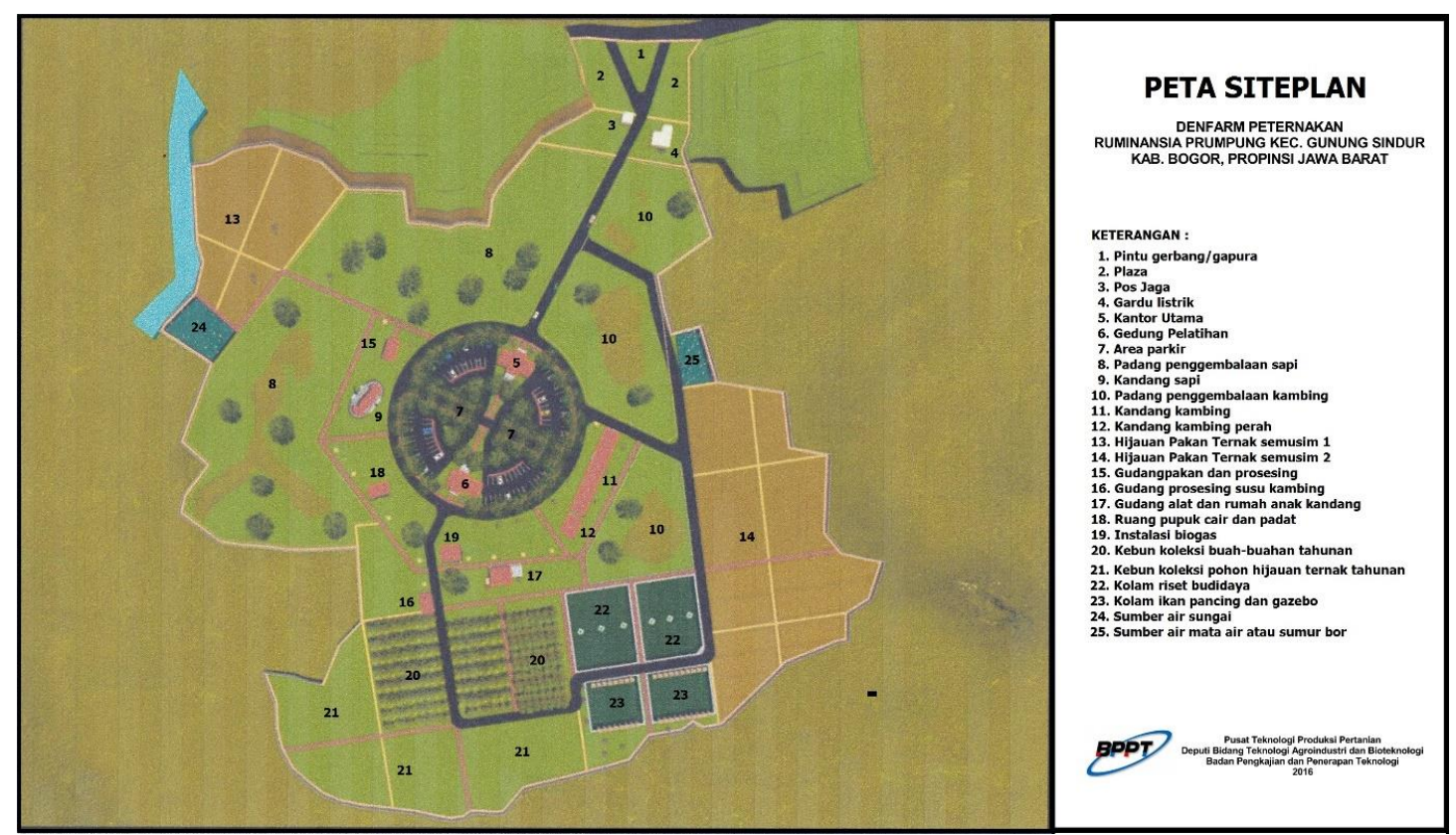

Gambar 3. Peta Siteplan KAPITAN Prumpung

Konsep penataan vegetasi di dalam KAPITAN lebih banyak didominasi tanaman atau hijauan makanan ternak, sisanya adalah pohon buah-buahan di kebun koleksi dan tanaman hias sebagai pengisi taman tematiknya. Hijauan pakan adalah semua jenis tanaman hijau yang dapat dikonsumsi oleh ternak ruminansia, tidak meracuni tubuh ternak dan zat gizinya dapat memenuhi kebutuhan hidup ternak (Hasan, 2012). Hijauan pakan ini diproduksi untuk mendukung penyediaan pakan yang baik untuk ternak ruminansia dalam jumlah maupun kualitas. Hijauan pakan terbagi ke dalam 2 kelompok besar, yaitu: (a) Kelompok rumput (Graminae), dan (b) Legum atau kacang- kacangan (Leguminosae). Keduanya memiliki hubungan yang sangat erat sebagai penyedia hijauan pakan untuk ruminansia (Hasan, 2012)

Hijauan pakan ternak yang umum diberikan untuk ternak ruminansia adalah rumput-rumputan yang berasal dari limbah pertanian (padi, jagung, dll) dan padang penggembalaan serta tegalan. Ransum ternak ruminansia yang lebih banyak digunakan adalah rumput. Hal ini dikarenakan selain harganya lebih murah juga untuk memperolehnya relatif lebih mudah. Produktivitas rumput relatif lebih tinggi dan lebih tahan terhadap tekanan defoliasi (pemotongan dan renggutan). Menurut Hasan (2012) pengertian rumput ditinjau dari metode 
pemanfaatannya terbagi dua, yaitu: (a) Rumput Gembala (grazing) yang dikonsumsi oleh ternak langsung di lapangan (padang penggembalaan) dan (b) Rumput Potong yang dikonsumsi oleh ternak ruminansia melalui perantara peternaknya (Cut and carry).

Beberapa alternatif hijauan pakan yang akan ditanam adalah: (a) Kelompok rumput (Graminae), yaitu rumput Gajah (Pennisetum purpureum), rumput Raja (Pennisetum purpupoides), rumput Setaria (Setaria sphacelata), dan rumput Benggala (Panicum maximum); (b) Kelompok Legum (Leguminosae), yaitu Sentro (Centrosema pubescens), Kalopo (Calopogonium mucunoides), Gamal (Gliricidia sepium), Kaliandra (Calliandra calothrysus), Turi (Sesbania grandiflor), Lamtoro Gung (Leucaena leucocephala), Orok-orok (Crotalaria juncea), Kelor (Moringa oleifera), Indigofera Sp, Jerami Kacang Hijau (Vigna radiata); dan (c) Kelompok lainnya yaitu Daun Nangka (Artocarpus heterophyllus), serta Daun Ubi Kayu (Manihot utilisima).

Pohon buah-buahan yang akan di tanam di kebun KAPITAN bisa terdiri kelompok tanaman punya nilai ekonomi seperti belimbing, duku, durian, jambu, nangka, rambutan, dan sirsak, atau kelompok pohon langka (hampir punah) yaitu kecapi, jamblang, cempedak, dll.

\section{KAPITAN Berkonsep GFP}

Perencanaan tapak pada kawasan KAPITAN dirancang sebagai demfarm dan litkaji peternakan bahwa fasilitas sapras untuk kawasan peternakan seluas $6,16 \mathrm{Ha}$ harus dirancang untuk memfasilitasi kenyamanan, kesehatan dan produktifitas ternak. Ventilasi yang baik, tersedianya pakan dan air dengan kualitas yang baik, penerangan dan kenyamanan ternak harus diperhatikan untuk meningkatkan performa ternak (Ensminger dan Tyler, 2006). Sebagai sebuah kawasan peternakan, ketersediaan pakan dalam memegang peranan yang sangat penting. Ketersediaan pakan yang cukup kuantitas dan kualitasnya merupakan salah satu faktor yang menentukan keberhasilan usaha pengembangan peternakan (Umiyasih et al., 2003). Kebutuhan ternak akan zat gizi terdiri atas kebutuhan untuk hidup pokok dan produksi. Kandungan nutrisi yang mencukupi dapat meningkatkan pertumbuhan bagi ternak, sehingga pertumbuhan ternak tersebut akan normal (Anggraeni et al., 2008). Untuk memenuhi kebutuhan hijauan pakan ternak dilakukan penanaman rumput gajah mini (Pennisetum purpureum cv. Mott) sebagai sumber hijauan pakan yang berkesinambungan. Rumput gajah mini tetap disukai ternak, baik dalam keadaan segar maupun kering berupa hay (Morais et al., 2007). Dilihat dari aspek produksi dan kandungan protein, rumput gajah mini lebih unggul dibandingkan dengan rumput Brachiaria decumbens, Brachiaria ruziziensis dan Paspalum notatum, sedangkan dari sisi palatabilitas dan kecernaan, rumput gajah mini sebanding dengan rumput $B$. ruziziensis dan tetap lebih unggul dibandingkan dengan rumput $B$. decumbens dan $P$. Notatum.

Usaha peternakan di Kawasan KAPITAN dirancang dengan pengelolaan yang profesional untuk mencapai hasil yang optimal. Untuk mewujudkan hal tersebut diperlukan pedoman budidaya ternak rumansia yang baik berdasarkan Good Farming Practices (GFP) menurut Department of Agriculture, Food and Rural Development Irlandia (2001) diintegrasikan dengan Pedoman Pelaksanaan Pengembangan Budidaya Ternak Ruminansia Potong Ditjennak (2016) yang dimodifikasi adalah sebagai berikut

\section{Pembibitan dan Reproduksi Ternak}

Secara umum, manajemen usaha peternakan seyogyanya mengacu Good Breeding Practices (GBP) dan GFP. Seleksi bibit merupakan bagian penting dari usaha peternakan. Prinsip seleksi bibit dilakukan berdasarkan penilaian visual (judging), silsilah, penampilan atau performa dan pengujian produksi. Sifat genetis yang perlu diperhatikan berhubungan erat dengan kemampuan adaptasi terhadap lingkungan dan kemampuan produksi. Bentuk atau ciri luar berkorelasi positif terhadap faktor genetis seperti laju pertumbuhan, mutu dan hasil akhir (karkas). Sebagai contoh rumpun sapi yang adaptif adalah rumpun sapi yang sudah lama berkembang di wilayah tersebut. Setiap rumpun sapi mempunyai sifat genetik yang berbeda dalam penyesuaian dengan lingkungan setempat karena ada interaksi genotipe-lingkungan.

Manajemen reproduksi ternak harus memiliki pengetahuan mengenai tanda-tanda berahi yang memadai. Umumnya peternak lebih senang memanfaatkan teknologi IB untuk perkawinan ternaknya. Hal ini disebabkan karena dengan IB peternak mendapatkan jaminan semen dari pejantan berkualitas unggul dan memiliki keleluasaan untuk memilih bangsa ternak yang diinginkan (Toelihere, 1993). Pada ternak sapi sebaiknya dikawinkan pada umur dimana pada umur 24-30 bulan sapi sudah beranak pertama (Sudono et al., 2005) Umur beranak pertama kurang dari 2 tahun dapat menurunkan 
produktivitas, baik untuk beranak lagi. Ball and Peters (2007) menyatakan bahwa untuk menghindari kemungkinan gangguan reproduksi dan mendapatkan angka konsepsi yang tinggi sebaiknya sapi dikawinkan minimal 60 hari setelah melahirkan. Menurut Abatany (2012) secara histologi, involusi benar-benar terjadi secara sempurna antara 50-60 hari setelah beranak. Menurut Izquierdo et al. (2008) selang beranak adalah jangka waktu (Calving Interval) dari saat induk beranak hingga saat beranak berikutnya yaitu selama 12-13 bulan. Sedangkan nilai normal Service per conception (S/C) menurut Nuryadi dan Wahjuningsih (2011) menunjukkan kisaran antara 1,6-2,0.

\section{Pakan dan Air Minum}

Manajemen Pakan dan Air Minum harus mempertimbangkan ketersediaan pakan yang cukup kuantitas maupun kualitasnya dan berkesinambungan merupakan salah satu faktor yang menentukan keberhasilan usaha pengembangan peternakan (Umiyasih et al., 2003). Kebutuhan ternak akan zat gizi terdiri atas kebutuhan untuk hidup dan pertumbuhan ternak. Kandungan nutrisi yang mencukupi dapat meningkatkan pertumbuhan bagi ternak, sehingga pertumbuhan ternak tersebut akan normal (Anggraeni et al., 2008). Dengan demikian pakan yang diberikan harus memenuhi kebutuhan ternak akan nutrien, palatabel, ekonomis, dan baik untuk kesehatan ternak.

Air merupakan nutrien yang sangat penting bagi ternak. Air yang diperlukan oleh ternak berasal dari air minum dan air yang terkandung dalam bahan pakan atau dari proses metabolisme di dalam tubuh. Kebutuhan air minum untuk ternak harus harus memenuhi baku mutu air yang sehat dan tersedia dalam jumlah yang mencukupi. Air minum pada ternak sapi diberikan secara ad libitum. Kebutuhan air tergantung pada kondisi iklim, bangsa sapi, umur dan jenis pakan yang diberikan. Sedangkan pakan yang diberikan berupa hijauan dan konsentrat. Hijauan ternak diharapkan berasal dari tanaman hijauan yang dibudidayakan di dalam kawasan peternakan yang sudah dirancang.

Disamping itu, pakan hijauan juga dapat dipasok oleh petani setempat dengan pola kemitraan dengan memanfaatkan limbah tanaman yang ada disekitar kawasan seperti jagung, padi dan lain lain. Sedang pakan konsentrat adalah pakan ternak yang mempunyai kandungan gizi yang tinggi dengan kadar serat kasar yang relatif rendah dan mudah dicerna. Menurut Firman (2010) Kosentrat adalah suatu bahan makanan berenergi dan protein yang tinggi, atau lebih tinggi dari pakan sumber serat untuk meningkatkan keserasian gizi dari keseluruhan makanan. Menurut GFP pemberian pakan hijuan segar minimal $10 \%$ dan konsentrat $0,4 \%$ dari bobot badan. Frekuensi pemberian pakan diatur dua kali sehari.

\section{Kesehatan Ternak}

Kesehatan ternak merupakan aspek yang sangat penting dalam keberhasilan berternak karena ternak mampu berproduksi dengan optimal jika dalam kondisi sehat (Mekonnen et al., 2006). Kesehatan ternak berkaitan system pengelolaan ternak mulai dari keamanan asal ternak, pakan, air dan lingkungan yang terjadi pada setiap mata rantai kegiatan (Bahri, 2008). Biosecurity merupakan salah satu tindakan penting dan strategis guna mencegah masuk atau keluarnya suatu penyakit dalam kawasan peternakan. Elemen dasar biosecurity antara lain isolasi, pembersihan, desinfeksi, dan pengaturan lalu lintas di kawasan. Aspek kesehatan hewan, antara lain: pengetahuan mengenai penyakit agar ternak menjadi resisten, pencegahan penyakit ke dalam peternakan dan pengobatan penyakit dengan penggunaan obat-obatan serta bahan kimia secara aman.

\section{Aspek Sarana dan Peralatan}

Sarana GFP diperlukan untuk usaha peternakan, seperti kandang ternak, kandang isolasi, gudang pakan dan peralatan, mess pekerja, dan unit pengolahan limbah. Ensminger dan Tylor (2006) menyatakan bahwa bangunan peternakan harus dirancang untuk memfasilitasi kenyamanan, kesehatan dan produktivitas ternak. Ventilasi yang baik, tersedianya pakan dan air dengan kualitas yang baik, penerangan dan kenyamanan ternak harus diperhatikan untuk meningkatkan performa ternak. Rancangan masing-masing bangunan harus memperhatikan lingkungan dan topografi sehingga kotoran dan limbah yang dihasilkan tidak mencemari lingkungan.

Lanskap harus ditata sedemikian rupa agar memudahkan melaksanakan kegiatan sehari-hari, memudahkan pengaturan drainase dan penampungan limbah sehingga tidak terjadi polusi dan pencemaran penyakit. Lokasi kandang sebaiknya lebih tinggi dari kondisi sekelilingnya dan terhindar dari kemungkinan banjir, cukup jauh dari pemukiman agar bau dan limbah peternakannya tidak mengganggu warga setempat. Letak kandang isolasi ternak yang sakit harus tersendiri, seperti halnya sarana penampungan limbah sehingga tidak terjadi polusi dan pencemaran penyakit dimana limbah 
ternak langsung mengalirkan limbahnya baik padat maupun cair ke saluran utama yang menuju tempat penampungan.

Kandang yang akan dibangun harus kuat, memenuhi syarat kesehatan, mudah dibersihkan, mempunyai drainase yang baik, sikulasi udara yang bebas dan dilengkapi tempat makan dan minum serta bak desinfektan. Sebaiknya bangunan kandang dibuat sedemikian rupa agar selalu mendapat cahaya pagi yang penuh ultraviolet. Sebagian besar peternak langsung mengalirkan limbahnya baik padat maupun cair ke saluran utama yang menuju tempat penampungan limbah umum. Disamping itu, setiap kawasan perternakan sebaiknya menyediakan sarana listrik yang cukup setiap saat sesuai kebutuhan dan peruntukannya seperti peralatan kandang, sanitasi kebersihan, peralatan pelayanan perawatan, peratatan budidaya hijauan ternak, pencacah rumput (chopper) untuk pemotongan hijauan, dll. Bangunan dan fasilitas peternakan harus dikontrol agar tidak membahayakan ternak karena di dalamnya dapat merupakan sumber yang penyebab kontaminasi bagi ternak seperti mikroba patogen, bahan kimia dan fisik yang dapat membahayakan tenak secara langsung dan tidak langsung

\section{Pemeliharaan Ternak}

Sistem pemeliharaan ternak sapi yang baik akan memberikan hasil produksi yang optimal, seperti dijelaskan Matondang dan Rusdiana (2013) bahwa produktivitas sapi lokal yang masih rendah disebabkan oleh manajemen pemeliharaan yang belum efisien Ada beberapa sistem pemeliharaan pada ternak sapi yang sering digunakan terdiri atas tiga bagian, yaitu: ekstensif, intensif dan semi intensif. Sistem pemeliharaan ternak di KAPITAN ini dirancang dengan sistem intensif. Aspek manajemen pengelolaan dan pemeliharaan ternak termasuk dalam kategori cukup penting, di mana kondisi ternak yang dipelihara dalam lingkungan yang sesuai dengan kebutuhan fisik dan fisiologis. Penerapan kesejahteraan ternak pada pemeliharaan ternak harus memperhatikan pekerja, pelayanan reproduksi, manajemen pakan dan air, kandang dan peralatan, dan manjemen kesehatan ternak.

Aspek ini dinilai baik bila prinsip dasar kesejahteraan ternak (animal welfare) terpenuhi, diantaranya adalah: (1) Bebas dari rasa lapar dan haus, cukup tersedia pakan dan air yang mampu memenuhi kebutuhan ternak; (2) Bebas dari rasa tidak nyaman, temperatur dan kelembaban sesuai, dan terlindung; (3) Bebas dari rasa sakit, luka, dan penyakit; pencegahan penyakit, pengamatan dini perilaku tidak normal, dan diagnosis yang cepat

dalam usaha mengatasi cedera dan sakit. (4). Bebas dari rasa takut dan stres, cekaman dan ketakutan yang menimbulkan penderitaan psikologis. (5). Bebas untuk mengekspresikan tingkah laku alamiah dan perilaku normal sebagai wujud kenyamanan hidup.

Pengelolaan secara administrasi seperti sistem pencatatan (recording) pada setiap kegiatan juga salah satu bagian yang penting. Pencatatan kegiatan bertujuan agar usaha yang dijalankan dapat terkontrol, terevaluasi dan diketahui perkembangannya. Pencatatan yang tertib dan teratur dapat membantu dalam menilai berhasil tidaknya usaha peternakan ini. Semakin baik pencatatan usaha yang dilakukan para peternak, akan semakin mudah pula dalam mengidentifikasi permasalahan pada peternakannya sehingga dapat menemukan solusi yang sesuai (Muriithi et al., 2014) Keberhasilan dalam usaha peternakan erat kaitannya dengan baik buruknya tatalaksana peternakan yang dijalankan oleh peternak (Makin, 2011).

\section{KAPITAN Berbasis Ramah Lingkungan}

GFP ini adalah standarisasi untuk menjalankan usaha peternakan secara optimal yang dirancang dengan konsep pelestarian termasuk upaya penanggulangan dan pencegahan pencemaran lingkungan di kawasan KAPITAN. Beberapa upaya yang dilakukan, antara lain: (1) Mencegah terjadinya erosi, berupa penghijauan dengan tanaman keras dan penanaman HMT di sekitar areal peternakan; (2) Mencegah terjadinya polusi dan gangguan lain yang berasal dari kawasan yang mengganggu lingkungan berupa bau busuk, serangga, tikus, pencemaran air sungai/air sumur dengan cara pengelolaan limbah dan pembasmian menggunakan insektisida; (3) Membuat unit pengolahan limbah yang sesuai dengan kapasitas produksi limbah yang dihasilkan; dan (4) Membuat saluran pembuangan kotoran, unit penampungan limbah serta penguburan bangkai ternak.

KAPITAN sebagai suatu kawasan peternakan akan mempunyai ciri utama dari suatu konsep dari pengintegrasian tanaman dengan ternak, dimana terdapatnya keterkaitan yang saling menguntungkan antara tanaman dengan ternak. Sistem usaha tani terpadu (integrated farming system) didasarkan pada konsep daur ulang biologis (biological recycling) antara usaha pertanaman, perikanan dan peternakan. Keterkaitan tersebut terlihat dari pembagian lahan (penataan vegetasi) yang akan dirancang menggambarkan saling terpadu 
dengan pemanfaatan limbah dari masing-masing komponen (Pasandaran et al., 2006). Konsep integrasi antara tanaman dan ternak ini memberi fungsi yaitu pembagian lahan pertanian dirancang untuk memenuhi kebutuhan HMT, dimana produk atau limbahnya dari satu komponen berfungsi sebagai sumber daya untuk komponen lain yaitu hijauan tanaman untuk pakan ternak. Limbah ternak yang berupa kotoran atau feses umumnya digunakan sebagai pupuk kompos (Syamsuddin et al., 2012) dan hanya sedikit yang dimanfaatkan sebagai biogas untuk kebutuhan energi di rumah tangga peternak.

Proses pembuatan biogas menurut Widodo dan Asari (2011) dimulai dengan menginput limbah ternak berupa kotoran, sisa pakan, air limbah (urin dan bekas mandi, bekas flushing) ke dalam reaktor Limbah lumpur dari instalasi biogas yang disebut bioslurry yang berupa cairan ataupun padatan dapat digunakan sebagai pupuk organik (Rajendran et al., 2012). Padatan tersebut sudah mengalami dekomposisi selama proses fermentasi di dalam digester atau reaktor, sehingga keberadaan mikroorganisme yang bersifat pathogen hanya dalam jumlah yang sangat kecil akan sangat baik untuk media tanam (Widodo dan Asari, 2011). Pendekatan zero waste, limbah ini dapat dimanfaatkan dan diolah sebagai pupuk sehingga mempunyai nilai ekonomis sehingga memberikan kontribusi cukup berarti secara pertanian ramah lingkungan dan berkelanjutan.

\section{KAPITAN Sebagai Agro-edu-wisata}

Penambahan fungsi KAPITAN sebagai sarana agro-edu-wisata mengharuskan adanya tambahan fasilitas untuk berwisata di tapak. Fasilitas wisata yang disebutkan antara lain: gerbang masuk, fasilitas informasi, area parkir, toilet, area piknik, taman bermain anak, rekreasi pancing, wildlife viewing dan interpretasi. Penerapan fasilitas wisata tersebut untuk KAPITAN tidak semua harus diterapkan namun disesuaikan dengan visi dan misi pengelola, ketersediaan dana dan kebutuhan pengunjung atau permintaan pasar.

Kegiatan yang ditawarkan antara lain berjalan di blok kandang sapi dan kambing/domba, tanaman HMT, pohon koleksi dan kolam ikan sambil mendapatkan informasi mengenai peternakan, HMT, buah-buahan dan perikanan tersebut, melakukan perah susu kambing/domba, memberi pakan langsung kepada hewan ternak, perbanyakan tanaman HMT, pengenalan kandang, green house, melihat proses biogas, pembuatan kompos, melakukan perawatan tanaman HMT, pemanenan buah, penanganan pasca panen dan melihat proses pengolahan produk menjadi berbagai jenis dan lainnya yang disesuaikan dengan kondisi tapak dan musim tertentu.

Konsep agro-edu-wisata akan memudahkan wisatawan dalam menginterpretasi berbagai obyek dan daya tarik wisata yang disesuaikan dengan tujuan wisata. Penyusunan rencana jalur wisata disesuaikan dengan konsep sirkulasi serta terintegrasi secara utuh dengan paket wisata yang ditawarkan. Pengunjung yang akan datang ke KAPITAN diharapkan bisa mendapatkan informasi tentang dunia peternakan, pertanian dan perikanan melalui kegiatan wisata terpadu.

\section{SIMPULAN DAN SARAN}

\section{Simpulan}

KAPITAN sebagai suatu kawasan peternakan yang akan menerapkan GFP secara konsisten dalam rangka upaya peningkatan produksi ternak rumansia melalui peningkatan populasi dan produktivitas ternak secara nasional. Desain lanskap KAPITAN diwujudkan dalam bentuk site plan yang didominasi pola geometris yang terbentuk dari elemen tapak seperti tanaman HPT dan tanaman pengisi taman tematiknya. Zonasi yang dibuat, yaitu: Zona umum (4\%), Zona rekreasi (9\%), Zona produksi $(81 \%)$, dan Zona pribadi $(6 \%)$. Kendala tapak terletak pada faktor-faktor fisik yang masih mungkin bisa diminimalisasi.

KAPITAN merupakan suatu kawasan peternakan yang mempunyai ciri utama dari suatu konsep berbasis ramah lingkungan dengan model integrasi tanaman dengan ternak, dimana terdapatnya keterkaitan antara hijauan tanaman untuk pakan, limbah ternak yang berupa cairan bioslurry sebagai biogas (energy) sedang padatan dapat digunakan sebagai pupuk organik. Pendekatan zero waste limbah ini dapat dimanfaatkan dan diolah sehingga mempunyai nilai ekonomis.

\section{Saran}

Setiap pengembangan ternak sebaiknya tetap mendapatkan dukungan dari pemerintah, swasta dan akademisi mulai dari penyediaan bibit, ketersediaan pakan, dukungan keswan, pemasaran dan kelembagaan lain termasuk permodalan untuk bisa mengoptimalkan produktivitas dan efisiensi usaha ternak yang berkelanjutan. KAPITAN sebagai suatu model kawasan peternakan diharapkan sebagai pusat education dan recreation yang berbasis iptek di 
bidang peternakan untuk semua lingkungan masyarakat.

\section{DAFTAR PUSTAKA}

Anggraeni, A., N. Kurniawan, dan C. Sumantri. 2008. Pertumbuhan pedet betina dan dara Sapi Friesian Holstein di wilayah kerja bagian barat KPSBU Lembang. Prosiding Seminar Nasional Teknologi Peternakan dan Veteriner. Pusat Penelitian dan Pengembangan Peternakan. Bogor.

Atabany, A. 2012. Efisiensi Reproduksi dan Produksi Susu Sapi Friesian Holstein (FH) Pada Generasi Induk Dan Generasi Keturunannya. Skripsi. Sekolah Pasca Sarjana, Fakultas Peternakan, Institut Pertanian Bogor. Bogor.

Bahri, S. 2008. Beberapa aspek keamanan pangan asal ternak di Indonesia. Pengembangan Inovasi Pertanian. 1(3): 225-242.

https://dokumen.tips/documents/aspekkeamanan-pangan.html Diakses pada 24 September 2018.

Ball, P. J., and Peters, A. R. 2007. Reproduction in Cattle. Third Edition. Blackwell Publishing. Oxford, United Kingdom.

Black, J. A. 1981. Urban Transport Planning : Theory and Practise. Cromm Helm . London.

Eckbo, G. 1995. The Art of Home Landscaping. Mc. Graw Hill Book Company. New York.

Ensminger, M. E. and H. D. Tyler. 2006. Dairy Cattle Science. 4th Edition. Pearson Education Inc., New Jersey.

Fahrudin, F. M., dan A. A. Hadi, 2013. Perancangan Lanskap Kebun Percobaan Sindangbarang Sebagai Sarana Agrowidyawisata. Jurnal Lanskap Indonesia 5 (1): 6.

Firman, A. 2010. Agribisnis sapi perah: Bisnis sapi perah dari hulu sampai hilir. Widya Padjadjaran. Bandung.

Gold, S. M. 1980. Recreation Planning and Design. McGraw-Hill Book Co. New York. Pp. 197

Hakim, Rustam, 2012. Komponen Perancangan Arsitektur Lansekap. Prinsip-Unsur dan Aplikasi Desain. Edisi kedua. Bumi Aksara. Jakarta. Pp. 383.

Hasan, S. 2012. Hijauan Pakan Tropik. IPB Pres Bogor dan Hasanuddin University Press.120p.

Izquierdo, C. A., V. M. X. Campos, C. G. R. Lang, J. A. S. Oaxaca, S. C. Suares, C. A.
C. Jimenez, M. S. C. Jimenez, S. D. P. Betancurt, and J. E. G. Liera. 2008. Effect of the offsprings sex on open days in dairy cattle. J. Anim. Vet. Adv. 7:1329-1331.

Makin, M. 2011. Tatalaksana Peternakan Sapi Perah. Graha Ilmu. Yogyakarta.

Mekonnen, M. H., Asmamaw, K., Courreau, J. F., 2006. Husbandry practices and health in smallholder dairy farms near Addis Ababa, Ethiopia. Prev Vet Med. 74(2):99 107.

Mersyah, R. 2005. Desain Sistem Budidaya Sapi Potong Berkelanjutan untuk Mendukung Pelaksanaan Otonomi Daerah di Kabupaten Bengkulu Selatan. Disertasi. Sekolah Pascasarjana, Institut Pertanian Bogor. Bogor.

Morais, J. A. D. S., Sanchez, L. M. B., Kozloski, G. V., De Lima, L. D., Trevisan, L. M., Reffatti, M. V., Cadorin Jr, R. L. 2007. Dwarf elephant grass hay (Pennisetum purpureum Schum cv. Mott) digestion by sheep at different levels of intake. Ciência Rural 37:482-487.

Matondang, R. H., Rusdiana, S. 2013. Langkahlangkah strategis dalam mencapai swasembada daging sapi atau kerbau 2014. J. Litbang Pertanian 32:131-139.

Muriithi, K. M., Huka, S. G., Njati, C. I. 2014. Factors influencing growth of dairy farming business in amentia south district of mere county, Kenya. IOSR Journal of Business and Management 16(4): 21-31.

Nuryadi dan Wahjuningsih, S. 2011. Penampilan Reproduksi Sapi Peranakan Ongole dan Peranakan Limousin di Kabupaten Malang. J. Ternak Tropikal 12 (1): 76-81.

Pasandaran, E, A., Djajanegara, K., Kariyasa dan F. Kasryno. 2006. Kerangka Konseptual Integrasi Tanaman-Ternak di Indonesia. Dalam: Integrasi Tanaman-Ternak di Indonesia. Badan Penelitian dan Pengembangan Pertanian. Pp. 11-31.

Rajendran, K., S. Aslanzadeh, and M. J. Taherzadeh. 2012. Household 2942.-biogas digesters-A review. Energies 5: 2911.

Sudono, A., R. F. Rosdiana, dan B. S. Setiawan. 2005. Beternak Sapi Perah Secara Intensif. Agromedia Pustaka. Jakarta.

Syamsuddin, A. R. Mappangaja, dan A. Natsir. 2012. Analisis manfaat program biogas asal ternak bersama masyarakat (BATAMAS) Kota Palopo (Studi Kasus Kelompok Tani Kampulang Kecamatan Wara Selatan Kota Palopo). Pp. 18. 
Toelihere, M. R. 1993. Inseminasi Buatan pada Ternak. Penerbit Angkasa. Bandung

Umiyasih, U., Aryogi, Y. N. Anggraeny, M. Zulbardi, dan Kuswandi. 2003. Analisis respon perlakuan pakan terhadap keragaan produksi sapi potong dara. Prosiding Seminar Nasional Teknologi Peternakan dan Veteriner. Pusat Penelitian dan Pengembangan Peternakan. Bogor.

Widodo, T. W. dan A. Asari. 2011. Inovasi Mekanisasi Mendukung Penyediaan Energi Rumah Tangga Petani. Edisi 1-7 Juni no. 3408 Tahun XLI. Agronovasi. Sinartani. 